\title{
Muslim Representation in Post 9/11 Hollywood: A Semio-Pragmatic Analysis
}

Mohammad Mahmoud Saeed Bekheet

Suez Canal University, Egypt 


\section{Abstract}

The significant role of movies in disseminating information and creating images of the real life is totally irrefutable. With the development of film production, critical and professional recognitions of films have not yet been developed along with popular recognition of films. This study is intended to investigate the image of Muslims represented in post 9/11 American movies through a semiopragmatic approach based on the multimodal analysis of the selected films. Chandler's categories of codes and Fiske's semiotic model are adopted in a qualitative method of analysis to uncover ideological and social (mis)representation of Muslims in American Cinema. Thus, this study contributes, in a modest way, to suggesting a systematic approach to the study of western films in order to appreciate and evaluate their communicative and aesthetic impact as a powerful mass medium using semiotic/pragmatic practices.

Key words: cinematic discourse, film semiotics, multimodal analysis, pragmatics, Islamophobia, cinema.

\section{INTRODUCTION}

Media today has a powerful impact on the audience and viewers everywhere in the world. Gunter (2008) states that media has the power to shape the awareness of audience. Media can affect the audience in more than one way and can impact them emotionally as well as psychologically. 
Hollywood, which represents American cinema, witnesses the production of the greatest film in the world of all times (Miller, 2007). Hollywood has a deep impact on the viewers everywhere, as it is considered the main source of entertainment in the modern world.

Films have an effective role within the society as one of mass media communication. Films communicate meanings through the manipulation of multiple codes and signs, whether visually or textual signs. The impact of films is very real and lifelike rather than other artistic works such as books, theatre, music, painting and others. Cinema works to bring to life real stories of common people. It communicates feelings, meanings, ideology, conflicts and politics. This can impact the viewers socially and culturally, as well as personally.

People everywhere show a kind of great interest in cinema and films, as they echo human personal experience that touches the mind and hearts easily through the group of social semiotic signs employed in filmmaking. The study focuses on analyzing hidden meanings and social semiotics which signify different ideologies and construct certain images in the mind of the viewers. Thus, this research work aims at filling the gap in the study of film discourse, for there are few studies which investigate political and social issues from the perspective of pragmatics and semiotics. 
Considering the scarcity of research on film discourse in general, this study aims at applying a semio-pragmatic approach based on the multimodal analysis of selected films to uncover semiotic resources manipulated in cinema. The study attempts to investigate the images of Muslims represented in American movies, due to the fact that American cinema is very popular and attracts the attention of the viewers everywhere. The purpose of this research is to analyze audiovisual representations of Muslims depending on uncovering the multimodal semiotic codes implicit in films, and used to communicate meanings and ideas through audio and visual media. Thus, this study suggests a modern approach towards the analysis of moving pictures through the manipulation of a linguistic technique that uncovers the semiotic modes, codes, and signs that communicate meanings.

Based on the above objectives, the present study attempts to answer the following questions:

1. What semiotic codes, resources and modes have been utilized by the producers of these films to construct or refute the idea of Islamophobia?

2. How are Muslim stereotypes represented in visual speech and nonverbal symbols of the selected films? 


\section{LITERATURE REVIEW}

The review of literature addresses the phenomenon of "Islamophobia", highlighting the view of the west on Islam and Muslims, in general, and the representation of Muslims in films. This section also addresses the theoretical background of the main topics relevant to film making, film semiotics and signs.

\section{Hollywood and Islamophobia}

Muslims and Arabs have been presented in American cinema through many characters before the September 11, 2001 terrorist attacks. Arab Muslims have been stereotyped in Hollywood as "blonde-lusting sheikhs or uncivilized terrorists". Since 9/11 many television shows, programs, and films tackled the issue of terrorism, showing Arab Muslims as criminals and villains (Yin, 2010, p. 103).

Exploring how and why Islamophobia was manifested following 9/11, Allen (2004) illustrates that many voices in the west have practiced Islamophobia, and that this fear of Muslims became even justified. His study concludes that the terrorist attacks of $9 / 11$ have made Islamophobia more acceptable, "which has enabled its expressions, inferences, and 
manifestations to locate a newer and possibly more prevalent societal resonance and acceptability" (p.2).

Since September 11, 2001, much of American and world politics, governments and media have focused on the issues of Muslim terrorism and extremism, especially in the Middle East region. The war in Iraq has attracted the attention of American community and created a sort of interaction between Americans and Muslims. Most Americans started to form a negative view of Muslims with many stereotypes reinforced in their minds about Islam in general. Modern research has revealed unfavorable attitudes toward Muslims, Muslim-Americans, and Islam generally (Davis, 2007; Panagopoulos, 2006; Traugott et al., 2002).

\section{The Representation of Muslims in Films}

Muslims have been introduced and represented through American cinema in different ways. Arabs and Muslims are usually introduced as terrorists in most cases. However, as Yin (2010) mentions, there was a tendency in Hollywood to represent Muslims positively as being good citizens, especially American Muslim population. There are roles that show Muslims participating in counter terrorism activities and rejecting extremism. Yet, Yin believes that this good portrayal of Muslims is limited to minor characters, and this does not leave a big impact on the audience. 
As for film studies discussing Muslim representation in media and film, Amirian (2012) conducted a research to investigate the images of Iranians represented in the Western movies. In his article, he analyzed a documentary movie called Iranium using Critical Discourse Analysis. Amirian argues that the movie manipulated some discursive strategies, such as positive self representation versus other negative representation, to create a stereotypical image about Iranians. He explains that the movie makers manage to create such a negative image by highlighting the negative stereotypes about Muslims through other discursive strategies such as actor description and euphemism. He believes that this film applied negative other-representation as a semantic macro-strategy to distort the image of Iranians.

\section{Film semiotics}

Films are considered artifacts that are created to carry meanings and construct concepts. Films consist of a complex system of signs including image, sound, language, costumes and music. All These codes or signs are manipulated by filmmakers to create meanings and communicate them to the viewers (Bateman \& Schmidt, 2012).

Elsaesser and Poppe (1991) reflect on the relation between linguistics and film studies, and explain that films convey meanings through images as well as language. They further illustrate that the cinematic technique employs 
both the image, as well as language, to create and communicate meaning. The significance of the cinematic image is that it depends on a number of visual codes to construct meaning implicitly, the same way language is used to create meaning directly. They view the spectator as a reader of a text who tries to understand the meaning of the message.

As Prince (1993) notes, Films are a kind of semiotic media of communication in the same manner that language is a semiotic process. He also argues that films depend on a wide range of semiotic codes to construct meanings and communicate them to the audience through the screen. To achieve this, filmmakers apply language, as well as the image, through the creation and selection of shots and angles. He further introduces the aspects of what he names the pictorial signs that are common in cinema. He focuses on those iconic and mimetic aspects that are used to construct meanings. He adds that it depends on the receiver to analyze the semiotic codes to understand the implicit meaning communicated through the use of such codes.

\section{Signs and codes}

Fiske (1990) introduces the concept of code and explains that codes refer to the system through which signs are organized. He further notes that signifying codes are considered as systems of signs. Fiske introduces some basic 
features that are common to signifying codes such as the paradigmatic and syntagmatic dimensions of codes.

Chandler (2000) mentions three kinds of codes: social, textual, and interpretive. The social codes include some subsets of codes like verbal, bodily, commodity and behavioral codes. The verbal refers to the language with all its linguistic features, whereas bodily codes refer to gestures, facial expressions and eye contact. Commodity sub-codes include costumes and fashion, and behavioral ones entail rituals and protocols. Mass media codes including cinema, radio and television fall in this category, as well. The last type of codes is the interpretative one which includes perceptual codes, ideological codes such as race, class and gender, and codes of production and interpretation. The latter sub-codes refer to the codes applied to encode and decode texts.

\section{METHODOLOGY}

The researcher adopts a qualitative method of analysis which is more of analytic and descriptive nature, since this research work is limited to a pragmatic and semiotic study of the selected films.

\section{Sample}


A group of three American films released in Hollywood post $9 / 11$ are selected for the purpose of this study. The films are Syriana (2005), Munich (2005), and Rendition (2007).

\section{Data Selection}

The selection of films is based on the following criteria:

1. popularity during the time of production,

2. Muslim characters being portrayed,

3. the time span, and

4. the political and social significance of films.

\section{Analytical Framework}

The films are analyzed using a model of analysis developed by the researcher based on Fiske's (1990) semiotic analysis model. This model depends on an extensive analysis of the types of codes. As the subjects of study are films, the researcher will employ analytical elements of study that are relevant to the semiotic analysis of visual images. The study tries to analyze the signs and the signified meanings represented through the various modes or codes applied through the films to construct the meaning. Since the codes and modes employed in each film differ, manifesting a wide range of visual, auditory and textual modes, the analysis will vary from one film to another. Hence, the researcher will use dominant semiotic signs and codes in each film. 


\section{DATA ANALYSIS AND DISCUSSIO}

After The attacks of $9 / 11$, there was a kind of change in Hollywood films concerning the ways they tackled issues related to Islam and Arabs. Although the same old stereotypes about Muslim continued to appear in many movies, one can notice a change in the way Muslims are represented in a good number of American movies. After the horrible attacks on 2001, the characters of Muslims and Arabs became common in many American films. Many film makers tried to reflect on the terrorist attacks of 9/11 and present them in Hollywood. Some others found it compelling to present a deeper analysis of the other - in this case, Muslims. Hence, a great number of movies were produced in Hollywood to discuss issues related to the Muslim community in the United States in general.

The positive representation of Muslims on the screen could be tracked through various features. There was less reference to Islamic faith with its rituals and beliefs in the course of actions. This helped to alienate the religious factor from the characters' actions as the audience starts to conceive them as just common American people. Other features that mark the change in the portrayal of Muslims was through physical appearance and clothing as well. Many of the characters broke the stereotype of dark-skinned Muslims with thick beards and moustache. Less traditional Muslim 
clothes were used to denote the character's religion, such as gowns and head cover or turbans for men. In the following section, the three post 9/11 films will be presented to analyze the way Muslim and Arab characters are introduced.

\section{Syriana (2005)}

"Syriana" is a 2005 geopolitical thriller film focusing on petroleum politics and the global influence of the oil industry in an Arab state in the Persian Gulf. It is an endlessly fascinating movie about oil and money, America and China, traders and spies, the Gulf States and Texas, reform and revenge, bribery and betrayal. Its interlocking stories come down to one thing: there is less oil than the world requires, and that will make some people rich and others dead. The film tells four parallel stories; the 'Emir Storyline' is about the traumatic association of the energy analyst Bryan Woodman with the son of a powerful Emir, Prince Nasir. Stereotypical representation of Muslims and Arabs is noticeable in the character of Nasir. Implicit signifiers are applied to form binary opposites between the two characters; of the most obvious ones is sophisticated versus Bedouin. The following two scenes reveal commodity codes used for this purpose.

Scene I: Ext. Desert ruins - Day 
(Tight on a falcon's face. Heat ripples across flat, white desert. It's hallucinogenic)

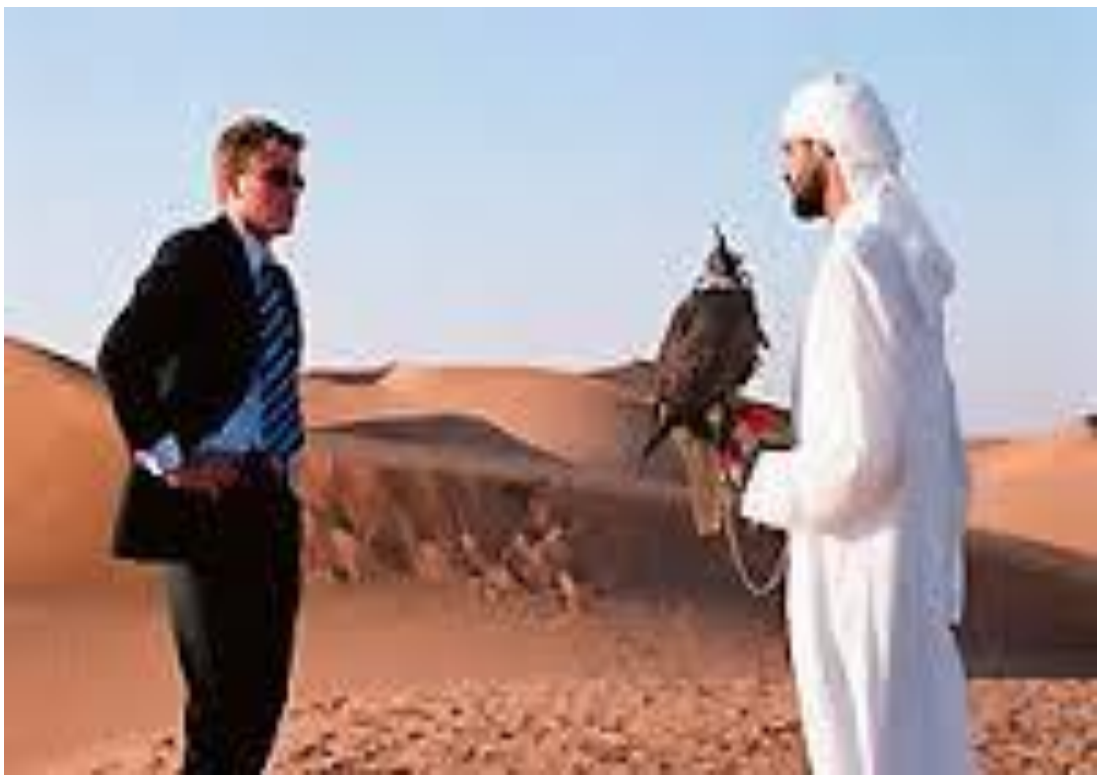

PRINCE NASIR: An ancestor of mine owned this bird's ancestor before Christ was born .... (The falcon catches an updraft and rises effortlessly) Six more North Field blocks will be available for development. We would like to offer your firm the right to represent them.

(Syriana, 2005)

Prince Nasir appears in his traditional Muslim attire of white plain gown and white piece of clothes over his head. The setting is in the Arabian sand, and the Falcon on Nasir's 
arm Symbolizes the authority he possesses over Bryan, as he is trying to haunt him and get him to work for his side.

Scene II: Int. Quiet room - Hotel suite - Day.

(Nasir speaks privately with Bryan)

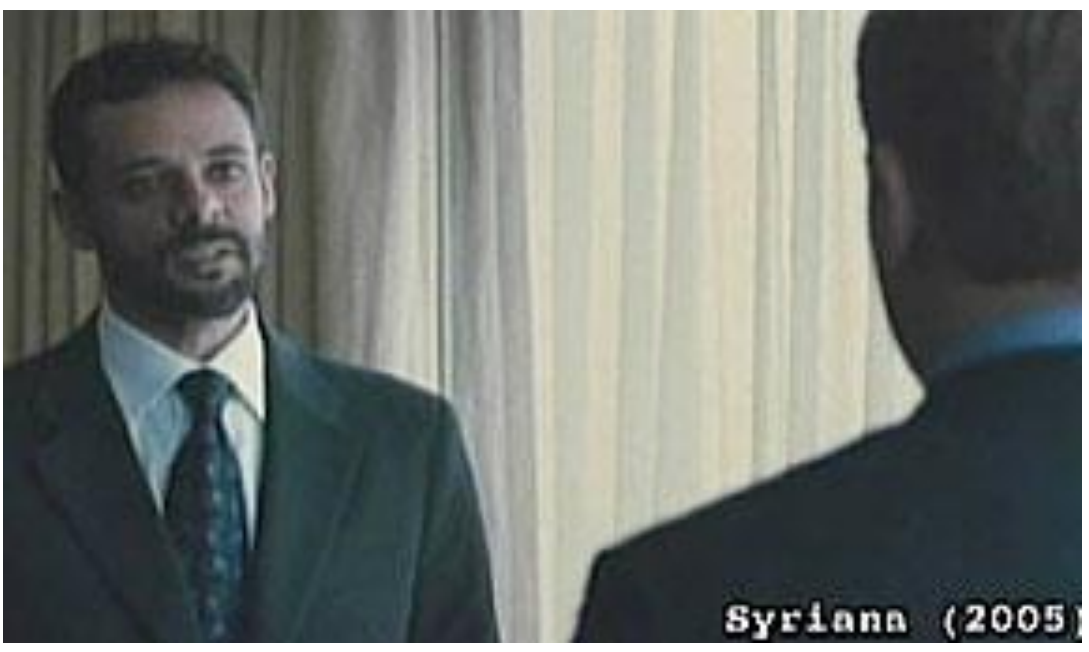

PRINCE NASIR: I studied at Oxford. I had a PhD from Georgetown. I want to create a parliament. I want to give women the right to vote (Syriana, 2005).

Commodity codes such as fashion and closing are manipulated through visual representation to reflect opposites between sophisticated Woodman and Bedouin Nasir, on the one hand, and different association with the prince, on the other. Along almost all scenes, Woodman is dressed up in a formal suit, as appears in the two shots, which can denote a smart, sophisticated businessman. Connotation of this 
character could be that he is uptight, symbolizing the American political and economic attitude towards Middle East. On the contrary, Nasir appears as the typical stereotype of a Muslim in the first shot: a bearded, turbaned man in a white robe, symbolizing his Bedouin nature as detached from modern civilization (in the American western view).

In his dialogue, Prince Nasir grants Woodman's company oil interests worth US\$75 million out of sympathy for the loss of his son. His clothing code reflects the western stereotype of Arab Emirs squandering their money and resources. The flat white desert setting signifies the greatest natural resource of oil around which the international interest, and conflict, is set. The confident posture of Nasir, with a falcon resting on his Arm, denotes power and influence. The falcon signifies power and wildness, since it is a wild predator that attacks other birds, and it also represents the huntsman. This connotation is suggested to reflect the Prince's power of winning Woodman as his economist advisor.

The opposites between wealth- and culture-oriented Nasir are reflected through the commodity code of clothing in both scenes. As opposed to the stereotypical appearance of a Muslim in the first shot, the Prince appears dressed up in the second shot when he is associated with high rank western education. The setting becomes more formal and modern in 
a classy suite room. The zoom and the cut focus on the Prince only, showing Woodman from his back. Nasir represents himself as an Oxford graduate and a Georgetown $\mathrm{PhD}$ holder. The film maker dresses Nasir up in a formal suit when associated with international education as detached from his Bedouin origins denoting sophistication and civilization bestowed upon him by western education. This connotation reflects the producers' intention to highlight American/Western superiority and dominance as opposed to Muslim Arab money and oil influence.

The signification of the changing commodity code of clothing for Prince Nasir over the two scenes, as well as the verbal code, can be briefly illustrated as follows: the contrasting images of the wealthy Bedouin vs. the highly educated. The formally dressed up American stands for the "sophisticated", "civilized", "educated", "open minded", and "reformer" white man. On the other hand, the Arab prince turbaned in white robe signifies the race, Islamic traditions, oil influence, the money-minded spendthrift Bedouin Arab. 


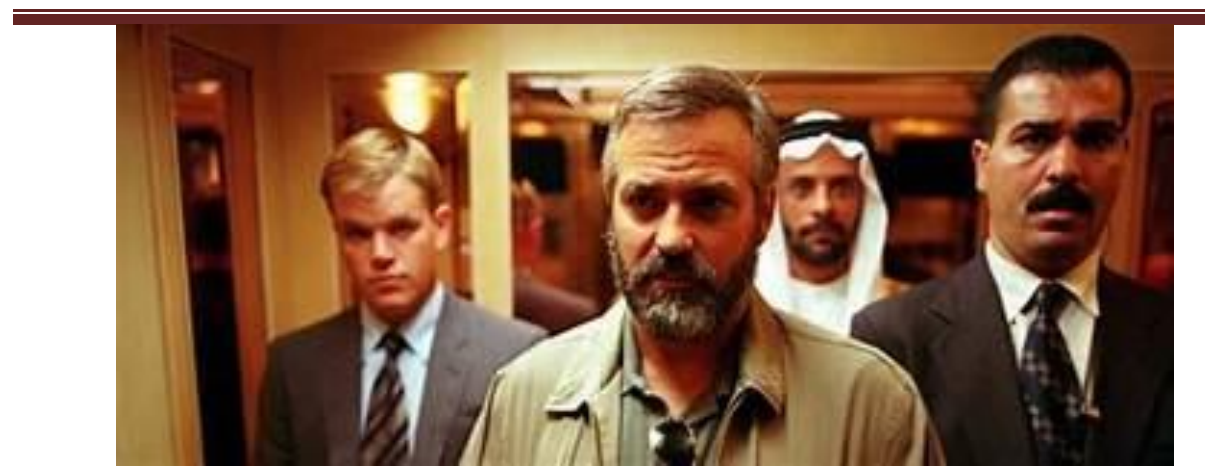

Framing is a very important role to creating relationships in the mind of the audience through the screen. In this shot, Prince Nasir appears in the background in a further shot in a little bit faded image. The American agent, on the other hand, is fronted in a close up on his face followed by the other two American characters. This indicates how inferior Muslims are to the WEest. It could also show that the West is always in the lead. The shot is taken to reveal the facial expressions of the three American men standing in front of prince Nassir whose image appears somewhat blurred. Again, the contrast in the commodity code of clothing reflects the contrasting identity of the Muslim Bedouin versus the civilized American. Unlike other scenes, where Prince Nassir is seen to be wearing full suit, he is dressed in his traditional Muslim attire.

\section{Munich (2005)}

This movie, released in 2005, features a reproduction of a true story in Hollywood. It is based on a true story of what is described internationally as black September which 
witnessed the assassination of Israeli athletes at the Munich Olympics in 1972. The film represents a drama that starts after the black September's assassinations where a team of Israeli private agents is formed and goes on a mission to haunt down and eliminate the Palestinians responsible for the assassination.

Muslim representation in this film is somewhat different. The main antagonists are not Muslims themselves, as Muslim characters play minor roles in this movie. However, Islam, Muslims and Arabs are profoundly represented in this movie through the events. The five Israeli agents selected to perform the task of killing the eleven Palestinians, who committed the assassinations, start haunting down them one by one. Then later on they started to question the morality of their mission and the killing they have been involved in. Some of the agents even quit the mission.

The main antagonist of the film is the character of Avner who is an Israeli from German origin. He started the mission with enthusiasm and a sense of revenge for the killing of the Israeli athletes. However, after killing few of the Palestinians responsible for the attacks, he starts to get disillusioned and reconsider his actions. 


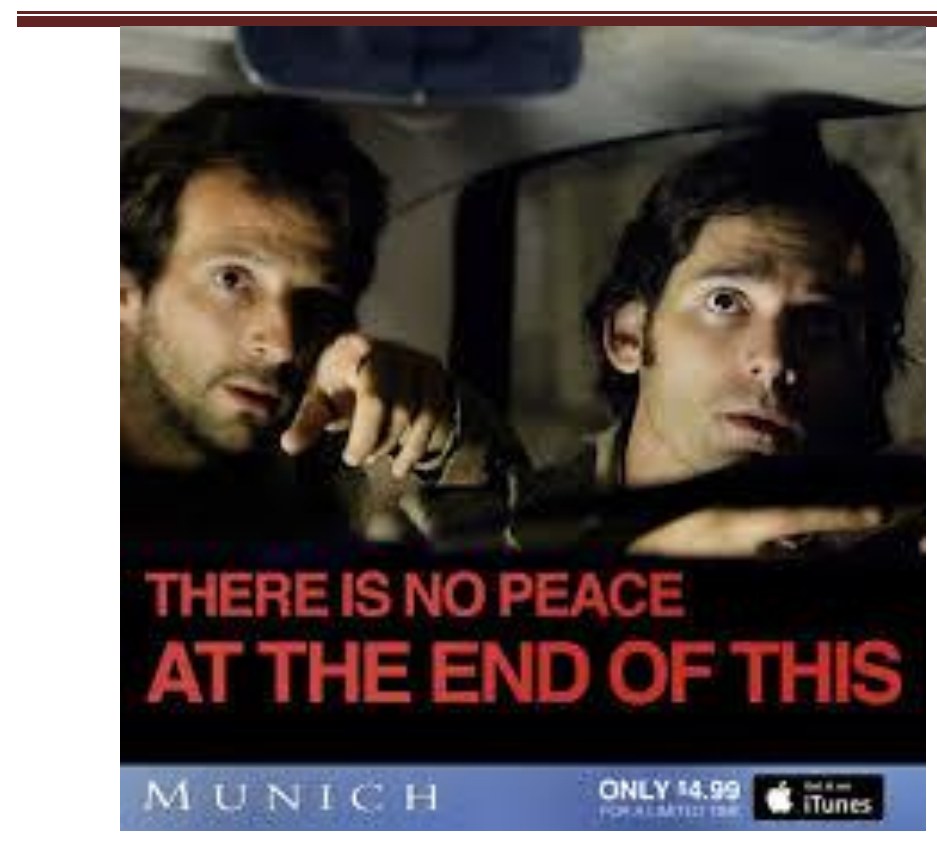

Avner quits the mission and returns to his family back in the United States where he starts to reflect on his mission. He becomes psychologically paranoid with flashbacks of the Munich massacre and pricks of conscience regarding the killing of the Palestinians. He starts to question the morality of his actions and whether his killings are truly justified or wrong actions. 


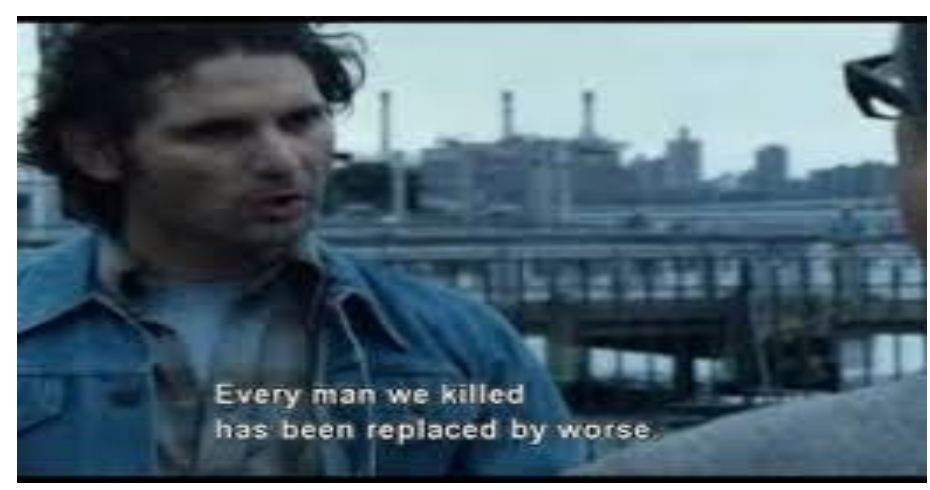

Avner refuses to return to work with the Israeli investigations again for this mission or any other missions. When Ephriam, the mission leader in Israel comes to the United States to meet Avner and urges him to return to Israel and rejoins the Mossad, the Israeli investigation organization, Avner rejects, and they have a conversation reflecting on the mission.

Avner : Did we accomplish anything at all? Every man we killed has been replaced by worse ......

Ephraim : You killed them for the sake of a country you now choose to abandon ...... You killed them for Munich, for the future, for peace.

Avner: There's no peace at the end of this no matter what you believe. You know this is true.

(Munich, 2005)

Not only Avner who questions the mission and its morality, but two other agents in his team started to think 
that what they are doing is futile. Robert is responsible for the bombs and planting theme in the scenes where they try to haunt down the Palestinians. He discusses this with Avner stating that "we are supposed to be righteous. That's a beautiful thing. And we're losing it. If I lose that, that's everything. That's my soul" (Munich, 2005).

The representation of Muslims in this film is limited to the Palestinians responsible for the assassinations while being hunted down and eliminated by the Israeli agents. There is not much revealed about their personality as they were simply introduced as terrorists. However, there is the character of Ali, one of the assassins involved in the black September's attacks. Although his presence in the movie is brief, he appears in one of the master scenes of this movie when he meets Avner and has a conversation with him, not knowing his true identity as an Israeli secret agent running after him. 


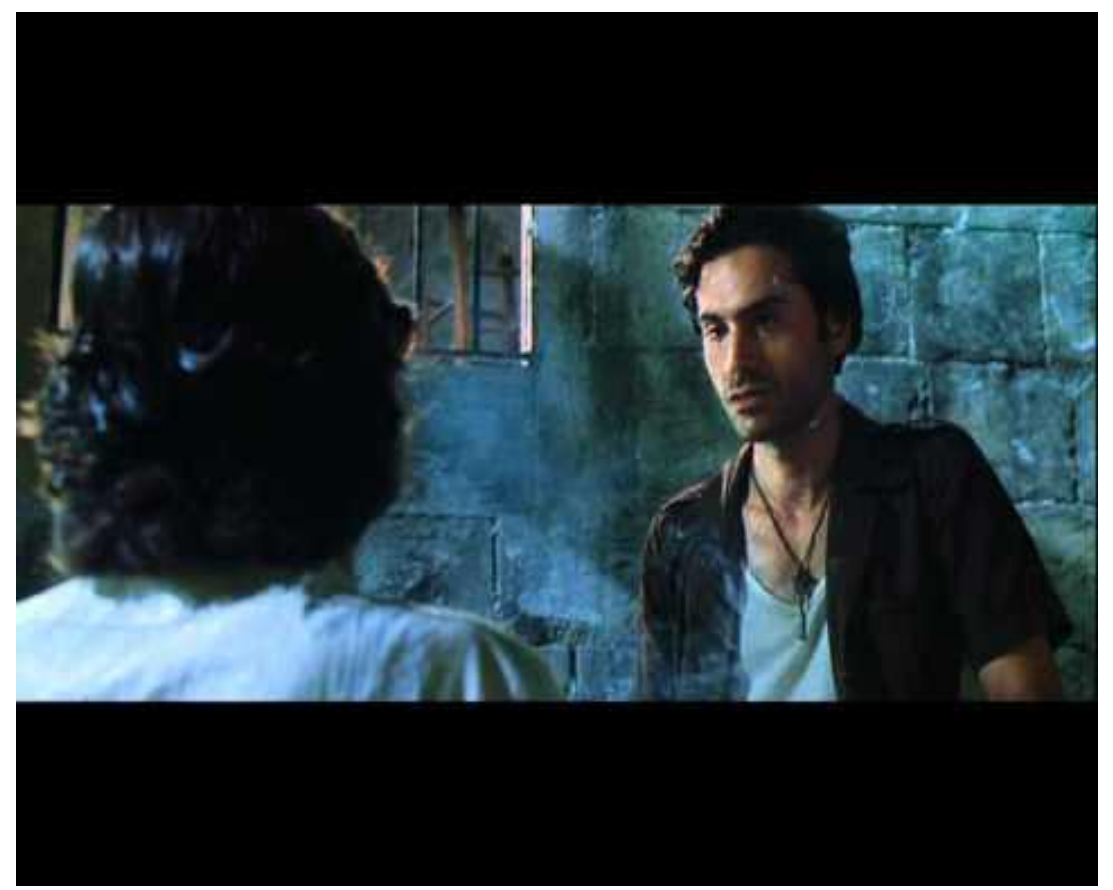

Ali starts to discuss the Israeli-Palestinian origin of conflict introducing the Arab point of view and providing an explanation of the motivation behind what the West calls terrorism. Ali affirms that Palestinians engage in terrorism because they just seek their home back.

Avner: Tell me something, Ali.

Ali : What?

Avner : Do you really miss your father's olive trees? Do you honestly think you have to get back all that... that nothing? that chalky soil and stone huts? Is that what you really want for your children? 
Ali : It absolutely is. It will take a hundred years, but we'll win. How long did it take the Jews to get their own country? How long did it take the Germans to make Germany?

Avner: And look how well that worked out.

Ali : You don't know what it is not to have a home. That's why you European Reds don't get it. you say, "It's nothing," but you have a home to come back to. ETA, ANC, IRA... we all pretend we care about your international revolution... but we don't care. We want to be nations. Home is everything.

(Munich, 2005)

Ali is given the stage to justify his action. For the first time on screen, the audience is faced with a terrorist who has a story to tell. Ali, who is introduced in this movie as a terrorist, is presented in this scene as a Palestinian young man who has a cause to defend. When Avner tells him that the world will condemn them for the bombing and killing and call them animals, Ali replies "But then the world will see how they've made us into animals. They'll start to ask questions about the conditions in our cages" (Munich, 2005). Ali's facial expressions are highlighted through close-ups, revealing him as more humane, and getting the audience to connect with him. 


\section{Rendition (2007)}

This film presents the story of an Egyptian American who becomes a terrorism suspect and how his American wife struggles to get him released from his secret detention outside the United States. The events of the film begin after an American envoy is killed in a terrorist bombing in an unidentified Arab country. The US secret investigations lead to a Muslim suspect who has been living in the United States for a long time. The American authorities arrest him at the airport upon arriving at Washington DC, returning from a trip in Africa. They send him to the country where the attacks took place for intensive interrogations that involve torture.

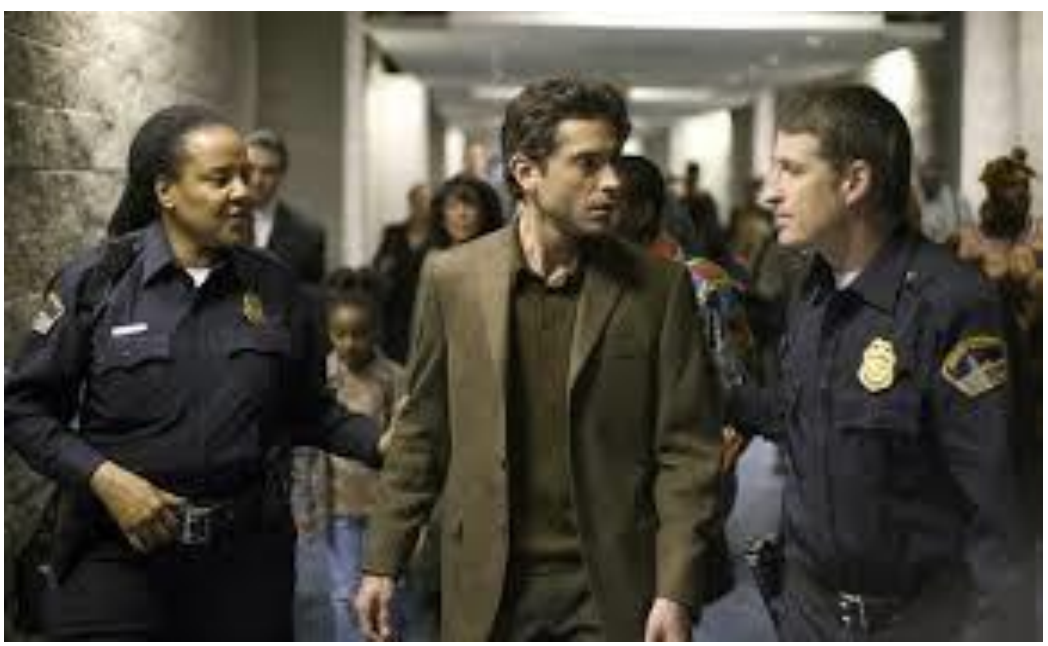

This movie represents the theme of Muslims and terrorism from a different perspective. Rather than focusing 
on the terrorist attacks and the efforts of the authorities to hunt down the criminals, the film offers a critique of the kind of investigations held by the American authorities to identify the terrorists. The main Muslim characters introduced in this film are not the terrorists, but rather the good Muslims. There are two main Muslim characters portrayed in this film: Anwar, the innocent suspect, and Fawal, The officer leading the investigations.

Anwar, the Egyptian American suspect, is sent to a secret detention in the North African Arab country to be interrogated thoroughly. The interrogation of Anwar is led by a high-ranked Arab inspector under the name of Abasi Fawal. The Muslim inspector is portrayed as a counter terrorism officer who tries to hunt down terrorists by all means, including torture. Despite Fawal being a cruel inspector, he is portrayed as a compassionate father on more than one occasion. 


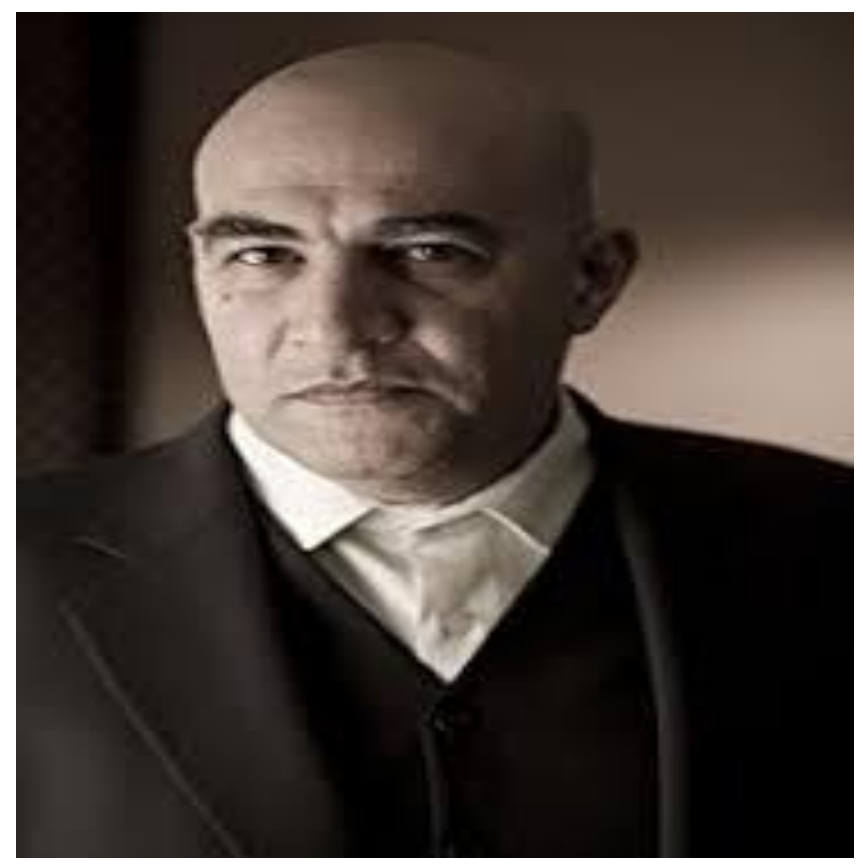

Fawal's appearance and his facial expressions are highlighted through the use of close-ups creating an aura of light around his face. There are a number of scenes that point to his extremely humane personal characteristics. For instance, one of the scenes presents him lying down on his bed with his little daughter in his arms as he playfully cuddles her. This particular scene offers a picture of the normal average father who cares about his family members, which serves to foster a positive image in the mind of the viewers. Besides, even after his daughter runs away with her boyfriend, Fawal tries to contact her and expresses his willingness to forgive her. His fatherly attitude towards his daughter and his compassionate tone help the audience discard the negative impression they formed earlier about the 
cruel inspector. Upon knowing about his daughter's death during the suicide attacks when she was trying to persuade her lover, Khalid, to abandon his terrorist mission, Fawal is so emotionally moved that he bursts into tears. His facial expressions are highlighted through a close-up on his face expressing his deep pain and agony over his daughter's loss.

The other Main Muslim character represented in this film is that of the suspect, Anwar El-Ibrahimi. He is an Egyptian born man who has been living in the United States for years and who is married to an American. Anwar is depicted in a picture that is rather different from the usual Muslims represented in Hollywood. He is introduced to the audience as a highly educated gentleman from his first scene. Viewers get to know that he is a chemical engineer who lives in Chicago with his pregnant wife and their young son. Anwar first appears in a scene informing his wife that he is heading back home to the US after attending a conference in South Africa. After this short scene the oriental nature of the music becomes more prominent with the playing of drums and tambourine, drawing the audience's attention to Anwar's ethnic background that is pivotal to the plot of this movie.

The portrayal of Anwar marks a change in the attitude of filmmakers towards the representation of Muslims in Hollywood. The actor selected to play this role is actually an Egyptian American in reality. He looks neat and good 
looking as he is introduced as a smart young engineer. The few scenes where Anwar appears before his apprehension show a nice good man who is well-dressed in casual suites. His facial aspects, along with his small body, serve to distract the image of the terrorist from the minds of the viewers who rather sympathize with him and feel that he is innocent. In the scene where he is tied up with his top body naked and placed on a seat to be interrogated by Fawal, the camera highlights his small body frame to show how helpless he is. His facial expressions are zoomed in to show his fear and weakness as well. Bright light, rather than shadow, is used to spot his body.

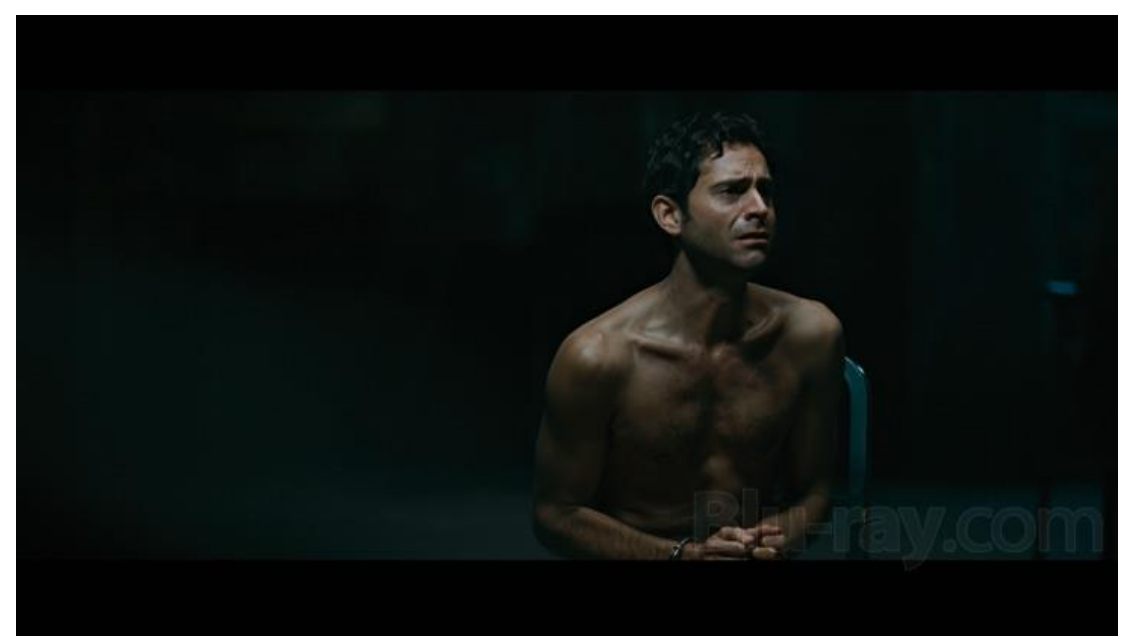

The way Anwar is presented to the audience puts him in the role of the victim rather than the guilty criminal. The 
audience is made to sympathize with him and feel involved rather than detached. The torture scenes where Anwar is brutally beaten reflect the suffering of Muslims in the war against terrorism. Anwar appears hung up from his arms and covered with blood and bruises all over his naked top body and bleeding lips. This image fosters the victimization of the Muslim character and condemns the interrogation authorities instead.

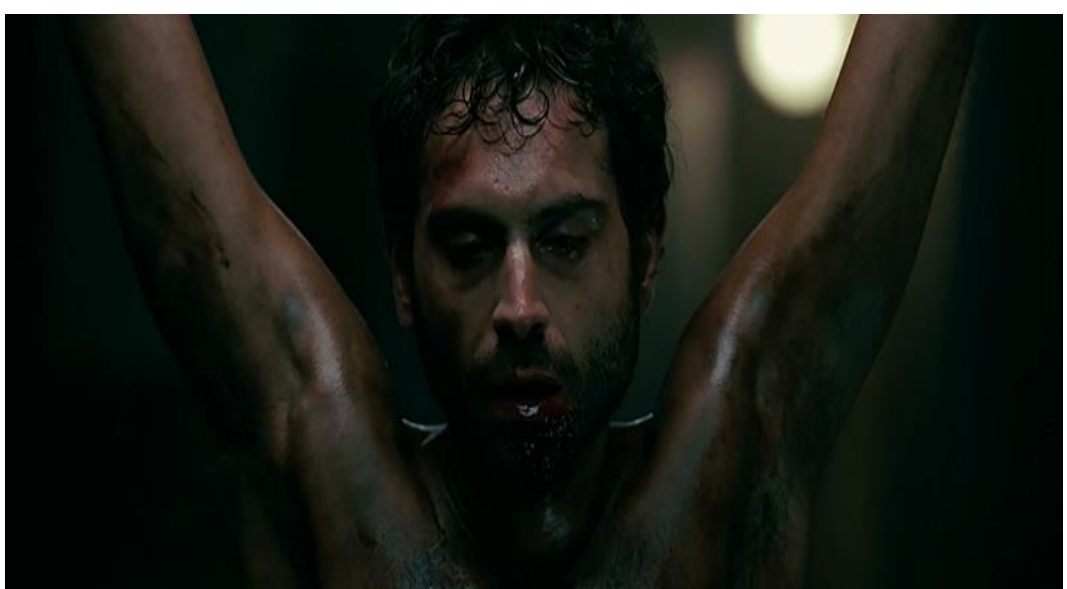

This movie offers the terrorists' perspectives in attempt to explore their psychological conditions and motivations. It clearly discusses how brainwashing takes place through the depiction of Khalid's character that is manipulated by the fanatic Muslims to perform terrorist bombings. and draws a line between "moderate Muslims" embodied in Fawal and Anwar, and other terrorists. Under Fatima's pleas, Khalid was about to change his opinion and abandon his mission; however, sensing his hesitation the leaders of the terrorist cell 
decide to shoot him and he involuntarily releases the handle of the detonator, causing the bomb to explode.

Nonetheless, Khalid's death evokes sympathy from the viewers, although he is a member of an active terrorist group. $\mathrm{He}$ is depicted in previous scenes as a lover who cares about Fatima. The director highlights his deep sadness over his brother's death under torture during an unseen investigation led by Fawal. All this contributes in presenting Khalid as a young man with psychological problems, due to the unjust way his brother was executed, rather than a hateful extremist with an urge to kill.

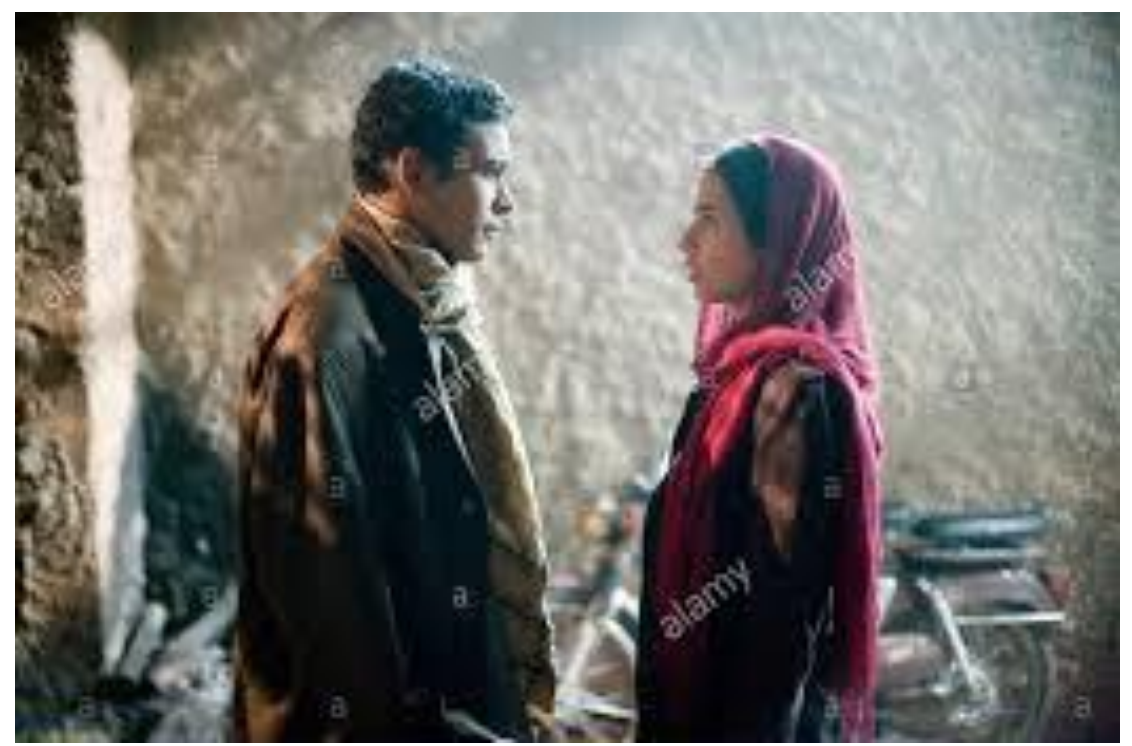


Still, Rendition's presentation of the Arabic language evokes previous old stereotypes about the Arabic language. The Arabic dialect used is Egyptian with insertions of Syrian and Lebanese terms. This does not consider the local differences across Arab countries.

\section{FINDINGS AND CONCLUSION}

The representation of Muslims and Arabs after the events of 9/11 witnesses a change in the Western perspectives related to Islam. Less stereotypical images of the terrorist Muslim are projected in the films released after 2001 and till the 2016. Muslims are portrayed in a more profound way revealing more humanistic features of their personalities. The good Muslim becomes a recurrent image in the film of this period. There is an increased portrayal of Muslim Americans and the Muslim immigrant community in the west. Muslim Americans are depicted positively as good and loyal citizens who oppose Islamic extremism and side with the US government in their war against terror. American Muslims are shown to reveal some compassionate feeling towards their fellow Americans. They have a sense of belonging to the American community rather than the Middle Eastern Muslims. 
It is very important to note that the Muslim characters in many post 9/11 films appear to play main roles in the films other than just minor roles or extras. They are essential to the story and no more appear as inferior to the white. The description of Muslim Americans in particular tends to be very positive, showing them as good citizens who are taking active part in fighting and rejecting extremism and terrorism. Throughout the analysis, it becomes evident that filmmakers make less reference to negative attributions of Islamic beliefs. There is even a kind of respect to Islamic religious rituals.

Based on the data analysis, the present study provides appropriate answers to the proposed research questions. The main findings are summed up and presented as follows:

\section{Semiotic codes framing Islamophobia}

There are some semiotic codes, resources and modes that have been utilized by the producers of these films to construct or refute the idea of Islamophobia. Other than the verbal codes applied to express directly the Western perspective concerning Muslims and the Islamic faith, other non-verbal codes are manipulated as well. The analysis reveals some bodily, commodity and behavioral codes used to denote Islamophobia. Verbal codes include the semantic choice of wordings to depict the Muslims on the tongue of the Westerners or White characters or the words the Muslim characters use to denote the white people. Other than the 
language, the costumes are selected to reveal how filmmakers decide that the audience should see the Muslims. Traditional Muslim attires are used as well to alienate the characters. As for bodily codes, the appearance of Muslim characters, either physical appearance, or genetic aspects associated with the actors selected to perform the roles, manifests the general fear of Islam expressed by the West. Behavioral codes are used to link Islam to extremism and terrorism through the portrayal of religious rituals of prayers, call for prayers, and Qur'an recitation just before bombing and terrorist actions.

\section{Visual representation of Muslims}

Stereotypes about Islam are mostly represented to the audience visually. The analysis of films reveals how Muslim characters are represented physically in light of the common stereotype of Muslims as mainly Middle Eastern Arabs. Costumes are designed to reflect a common stereotype of Muslims as being Bedouin and uncivilized. Most characters are portrayed as wearing the traditional Bedouin attire featuring the gown and head cover for men. The Muslim terrorists are introduced as being in a formal mission through the military baggy-style clothes in green or beige.

The more balanced representation of Muslims marks the manipulation of the same visual codes, but rather positively. Actors selected to portray the Muslim characters on the screen are handsome and good looking, featuring neat 
and attractive looks. Some of them have lighter skin color and colored eyes. They appear in modern costumes, featuring suits and casual wear, rather than the traditional Islamic attire. They are shot with close-ups reflecting their personal feelings and usually in the light, rather than darkness.

\section{Implications of the study:}

The study concludes that there is a significant change in the way filmmakers portrayed Muslim characters in films. There is a tendency to provide less stereotypical representations of Muslims in general. This change of attitude in the American filmmaker's perspective marks a significant positive social and cultural development in the relation between the West and Islamic nations. The more positive fair representation of Muslims in the cinema is achieved, the better consequences could be achieved on the social and cultural levels. This highlights the role of the media in general, and cinema in particular, in narrowing the gaps and crossing bridges between cultures.

The study also highlights the importance of the multimodal semiotic codes and signs in constructing a certain image whether positively or negatively. It sheds lights on the other signs that can be used to communicate meanings implicitly, and which usually leave a more profound impact

on the viewers and audience than language. 


\section{Limitations of the study:}

Despite the linguistic and cultural implications provided by the current study, it is limited in several ways that might be addressed in future research. The main limitation of the study could be the limited number of films selected for the purpose of this study. It was very difficult to include all the films that represented Muslims and Islam in the American cinema, since we have over one hundred films portraying Muslims and Arabs throughout the history of cinema in Hollywood.

Some limitations within the study occurred due to the difficulty of analyzing visual images in general. When approaching film analysis, the researcher found himself dealing with a multitude of codes and signs that carry multiple layers of meaning and need to be analyzed. This forms a huge task for any single researcher, and no one study can analyze all codes manifested in a given film. Thus, the researcher was selective in the scenes and shots to be analyzed and displayed for readers in the current study.

\section{Suggestions for further research:}

The study recommends the following:

- Further studies need to be conducted to focus on the audio visual representation of stereotypes in general as represented in Hollywood. 
- It is compelling to investigate the auditory aspects of films, represented in music, sound effects, and intonation.

- Muslim filmmakers should manipulate the multimodal semiotic resources available for films to communicate real images of the Muslim that face the common stereotypes represented by the west. 


\section{References}

Allen, C. (2004). Justifying Islamophobia: A post-9/11 consideration of the European Union and British contexts. The American Journal of Islamic Social Sciences, 21(3), 1-25.

Amirian, M. (2012). A critical discourse analysis of the images of Iranians in western movies: The case of Iranium. International Journal of Applied Linguistics \& English Literature, 1(5), 1-13.

Bateman, J. A. \& Schmidt, K. (2012). Multimodal Film Analysis: How Films Mean. New York: Routledge.

Bradshow, S. (Producer), \& Gaghan, S. (Director). (2005). Syriana [Motion picture]. United States: Warner Bros

Chandler, D. (2000). Semiotics for beginners. Retrieved from

http://www.aber.ac.uk/media/Documents/S4B/semiotic.html.

Davis, Darren W. (2007). Negative Liberty: Public Opinion and the Terrorist Attacks on America. New York: Russell Sage Foundation.

Elsaesser, T., and Poppe, E. (1991). Film and Linguistics. The Encyclopaedia of Language and Linguistics. Oxford: Pergamon Press.

Fiske, J. (1990). Introduction to communication studies. London: Routledge. 
Golin, S. (Producer), \& Hood, G. (Director). (2007). Rendition [Motion picture]. United States: New Line Cinema.

Gunter, B. (2008). Media violence: Is there a case of causality?. American Behavioral Scientist, 51(8), 1061-1122.

Kennedy, K. (Producer), \& Spielberg, S. (Director). (2005). Munich [Motion picture]. United States: DreamWorks.

Miller, B. (2007). Does Hollywood have a negative impact on the world? Retrieved from http://www.helium.com/items/432855-does-hollywood-havea-negative-impact-on-the-world.

Panagopoulos, Costas. (2006). "The Polls-Trends: Arab and Muslim Americans and Islam in the Aftermath of 9/11." Public Opinion Quarterly 70(4): 608-624.

Prince, S. (Autumn, 1993). The Discourse of Pictures: Iconicity and Film Studies Author(s). Source: Film Quarterly, 47(1), 16-28. Retrieved from University of California Press Stable: http://www.jstor.org/stable/1213106Accessed:

Traugott, Michael et al. (2002). "How Americans Responded: A Study of Public Reactions to 9/11/01." PS: Political Science and Politics 35(3): 511-516.

Yin, T. (2010). Through a screen darkly: Hollywood as a measure of discrimination against Arabs and Muslims. Duke forum for law \& social change, 2, 103-123. 